\title{
The Salem Connection: American Contacts with Early Colonial New Zealand
}

\author{
JOAN DRUETT
}

At midnight on 4 June 1831, a black-painted brig slipped silently into the Bay of Islands. It was a noteworthy event, because the vessel, named Charles Doggett, was the earliest recorded visitor to New Zealand from the port of Salem, Massachusetts. Dozens of New England whaling ships had called at the Bay of Islands since the Hannah and Eliza of New Bedford dropped anchor on 24 January 1806, yet none of them hailed from Salem. The merchants of that city had little interest in the greasy trade, being firmly focused on the riches of the East Indies and the Orient. ${ }^{1}$

Salem traffic in the East had begun in 1786, when Elias Haskett Derby sent his brig Grand Turk to Mauritius, where the captain, Ebenezer West, established a depôt for freight storage and cargo redistribution. After that, he steered for Canton to bargain for silks, teas and nankeens, which sold so profitably at home that a stream of fellow Salem captains followed briskly in his wake. Mauritius became an important entrepôt, from where Salem traders fanned out across the Indian Ocean and into the South China Sea, voyaging to Muscat for gum arabic, Bombay for cotton, Java for coffee, Manila for indigo, Sumatra for pepper and Canton for tea. ${ }^{2}$

A typical outward manifest was that of Derby's ship Astrea, which in 1789 was entered at Canton with a speculative cargo comprising snuff, beef, salmon, ginseng, tobacco, shoes, silver, plate, spermaceti candles, alcoholic spirits and wine. Of greatest value was the specie - thirty thousand dollars' worth. Costing a fortune at the time due to its scarcity, silver was nonetheless a necessary investment, because it was the only trade Chinese merchants would readily accept. Thirty-five years later, however, an alternative was found in the equatorial Pacific - because of the good luck of the captain of the same black-painted brig that slipped into the Bay of Islands in June 1831, William 'Old Glory' Driver. ${ }^{3}$

Driver, born in Salem on 17 March 1803, went to sea at the age of fourteen, then rose in the ranks over a series of Mediterranean voyages. His first South Seas voyage, beginning in 1824, was as first mate and trading officer of the Salem trader Clay, under the command of Captain Benjamin Vanderford. The brief from the ship's owners, Nathaniel L. Rogers and Bros., 
was to take the Clay to the Fijian Islands and procure a cargo of bêche de mer - sea-slugs. These were in hot demand in the East as a tonic for flagging virility and would fetch up to 40 Spanish silver dollars per picul in the Manila market. ${ }^{4}$

Getting a good haul of the slow-moving, gristly, phallus-shaped creatures was easily managed by scooping them off the bottom of a reef-enclosed lagoon. However, they had to be cured in a particular manner, or the cargo would be unmarketable - and William Driver had no idea how to do it. Providentially, however, he was accosted by 'a group of Manila pirates, who had murdered their captain, Hosea Boyes, and all his officers, destroyed his brig, the Conception, and now were selling off the trappings of the looted ship. Not only did the pirates show Driver how to cure the catch - a complicated process of gutting the slugs, boiling them in a large cauldron (like a whaling try-pot), rinsing them thoroughly in fresh water, and then smoking and drying them in a specially built 'batter' house - but they sold him the necessary kettles. A cargo weighing 600 piculs was taken to Manila, where it was sold at the equivalent of US\$32 per quintal, for a total 25,600 silver dollars. Driver reminisced in a letter to the Salem Register: 'Never was a voyage so dependent on good luck and so successful. ${ }^{5}$

The ship returned to Fiji, where Driver had left a gang of assorted locals and pirates catching and curing sea-slugs, and took on another cargo, sold at the same gratifying price. Vanderford then decided that it was time to go home. As the Clay headed east, however, they spoke the Quill, another Rogers-owned trader. William Driver shifted over to the other ship and headed back to the Fijian lagoons. Not until 1830, after obtaining and selling well over 1,000 piculs of bêche de mer, did he return to Salem, where he was given command of the Charles Doggett. On 14 January 1831, he left Salem in a snowstorm. At the end of a slow passage, a five-day gale forced him to bring the Charles Doggett into the Bay of Islands, to repair damages and replenish his freshwater barrels. ${ }^{6}$

As we have seen, he arrived at midnight on 4 June. Next morning, Driver visited the mission at Paihia, 'on the other side of the Bay, a distance of seven miles, to get water'? The missionary, Rev. Henry Williams, confirmed this sojourn, writing in his journal the same day: 'The Captain landed with whom we had much conversation.' ${ }^{8}$ In particular, Williams noted Driver's boast that 'it is universally observed that the crews of the American Ships conduct themselves with that propriety which is unknown by our own [English] countrymen in these seas'.

Overt patriotism was apparently typical of Driver, known then and since as 'Old Glory', his nickname for the US flag flying from his spanker gaff. Henry Williams retaliated by informing Driver that he was perfectly familiar with the nature of American seamen already. Driver recorded that not only 
had Williams been ' $1^{\text {st }}$ Lieut. of the Frigate Endimaen [Endymion]' when she had soundly defeated the US frigate President but he had also crewed the captured President to Bermuda: '[G]ot sick of war then, and took up the Cross. Fit man for New Zealand. ${ }^{10}$

From there the encounter went rapidly downhill. Williams tried to buy trade goods from Driver at the advantageous rates he was used to getting from the whaleship captains: 'Occupied a considerable time with the American Captain, endeavouring to purchase some trade - too dear. ${ }^{11}$ Consequently, when Driver requested free access to the mission stream at Paihia, it was easy for Williams to refuse. Then Driver hired a chief, Pomare, who agreed, for a musket, to escort the brig's boat to Paihia and supervise the filling of the barrels. Williams turned Pomare and the boat away. Driver next resorted to a written complaint, Williams recording on 19 July that he 'rec'd a note from the American ship respecting the watering on our ground, as his people had rec'd notice to quit'. ${ }^{2}$

The missionary cancelled prior appointments, 'as I had a very unpleasant matter to settle with the American Captain', and made his way to the Charles Doggett, where he found 'the Captain very angry and highly indignant that his people were prevented from watering on our ground'. ${ }^{13}$ Driver demanded to know what right the missionaries had to deny him water, and Williams retorted that the stream was on private property and that as private citizens, they could do with it as they wished. As he wrote:

He [Captain Driver], however, did not appear disposed to consider anything but his own convenience, and said that he had desired Pomare to water the ship and he should require him to go to the place in question, for which he had promised him a musket, and if that would not do he should give him two, if that would not accomplish it he would give him ten, and if that should fail he would give him something that would do. ${ }^{14}$

Seduced by this offer, Pomare proved 'as obstinate as the Captain', leading a party of his own people to the stream to fill the casks. Williams had arrived there first, however, and as the chief 'was there with natives only', Pomare was deterred enough to take his men and the empty barrels away. Williams 'determined to take up my abode at the place for the night to prevent further proceedings', and a number of mission boys accompanied him, 'they feeling the great importance that we should be preserved from any encroachment on the part of the shipping'. The mid-winter air was nippy, but they lit a large fire and passed a reasonably comfortable night. At first daylight, Pomare and his men returned, just as Williams had expected, but carried away their empty casks without any fuss once they spied the reception committee. Then Captain William Driver arrived but 'departed as he came, in silence and I 
felt extremely thankful to our Heavenly Father who had thus protected us from insult, and had given us the victory', wrote Williams. ${ }^{15}$

To make sure that it could never happen again, the boys felled the trees that grew about the stream, effectively preventing boats from coming up, and set a fence across the entrance. Then, to emphasise that this was private property, they dug up a nearby field for a garden. Captain Driver took the hint and sailed away.

This trivial matter augured badly for future relationships between the mission and Salem captains. There was an even more important outcome, however - an effort to turn the Bay of Islands into an entrepôt, along the lines of Derby's base in Mauritius. As William Driver reminisced a halfcentury later:

I learned there from Gilbert Marr [Mair], merchant, amd Mr. Williams of the mission at "The Pai", that the port of Sydney, N.S.W., was open, and that "a good trade might be done there by us", in staves, oars, pitch, resin, flour, tobacco, and a sprinkling of New England rum ... Thought a ship bound to Manila or China, during the Northeast monsoon, could save some thumping and would lose but little time by bringing such 'traps' here and selling or consigning them, and then away for Sunda or Timour Straits. ${ }^{16}$

Driver communicated this idea in a letter to the brig's owners, which he consigned to Salem via a homeward bound whaling ship. That done, he set sail to Tahiti for provisions and fresh water, where he was accosted by 65 descendants of the Bounty mutineers, desperate to get back to Pitcairn. He took them all on board, leaving Tahiti on 14 August, delivering them to Pitcairn Island 23 days later and then heading for Fiji and Manila. ${ }^{17}$ Finally, in the northern spring of 1832, he arrived home with a full freight of highly valuable sugar, plus a between-decks cargo of $1600 \mathrm{lb}$ of tortoiseshell (actually turtle shell), worth over US $\$ 20,000$, and 'bundles of bows and arrows, war clubs, etc.', to find that Rogers Bros., having received his letter, were fitting out their ship Tybee for the south Pacific trade. ${ }^{18}$

The Tybee cleared from the Salem Custom House on 27 April 1832, with one of their most experienced captains, Charles Millett, and a crew of thirteen that included Nathaniel Rogers' protégé, 20-year-old John Brown Williams, who served as her clerk. In November the ship called at the Bay of Islands to build and set up warehouses 'some miles distant' from Kororareka, where consignments could be stored, just as had been done in Mauritius 46 years earlier. By May 1833 the Tybee was in Sydney, the first American vessel to enter that port since the war of 1812-1815. Leaving on 8 June, the Tybee made a quick passage to Salem, mooring at Derby Wharf on 20 October 1833 to discharge the first pastorally produced Australian 
cargo exported to the United States. It included 4800 cattle hides and 1000 kangaroo skins. ${ }^{19}$

Meanwhile, Driver had been given command of the bark Black Warrior. While Millett was fitting out the Tybee for another voyage, Driver sailed direct to Sydney with a freight of naval stores, arriving in October 1833 to find 'almost a famine' and the government in desperate need of flour. $\mathrm{He}$ went on shore to set up a depôt, sending the Black Warrior back to the States in charge of his first officer, Joseph Rogers. In August 1834 Rogers returned to Sydney with 1600 barrels of flour, which had cost just $\$ 4.64$ per barrel in New York, and which Driver sold for seventy shillings (\$16.75) per barrel, at a profit of almost $\$ 20,000 .{ }^{20}$

In September 1834 the Black Warrior, still with Rogers in command, headed for Hobart, to negotiate for whale oil from the American whalers there. After taking on a part cargo of 24,946 gallons, Rogers sailed for the Bay of Islands, arriving on 6 October to find the Tybee at anchor. The sister ship also had a part cargo, so this was a chance to combine the two, freeing up the Tybee and saving warehouse space. The crew got out the long boat, rigged a derrick, and transferred freight, while Captain Rogers bargained for provisions: 'found it hard trading, the natives most of them back in the country planting their Potatoes'. ${ }^{21}$

On Monday 13 October 1834, the two captains exchanged quarterdecks, Rogers taking charge of the Tybee for another south Pacific trading cruise and Charles Millett taking over the Black Warrior for the voyage home. He sailed to New York to deliver the Tybee's cargo, along with his own oil, and in April 1835 was back in the Bay of Islands with a freight of gin and muskets to store, the muskets having cost $\$ 1.25$ each in New York when bought in lots of four hundred. It had been an exciting passage. In January, when they had called at the Society Islands to collect coconut oil trader Thomas Stanfield, left by Captain Millett during a previous voyage, they found he had gone insane and the natives had stolen all his trade goods. Running out the guns solved the problem: the cowed locals returned both Stanfield and the oil. Then, on the way to New Zealand, the cooper and the steward mutinied, to be overwhelmed with the aid of a boarding pike, wielded by the mate, Charles Mugford, and a sword, plied by the captain himself. ${ }^{22}$

Once anchored, the Black Warrior crew filled up their water casks (off Kororareka), dried their sails, and 'got off from the shore four tons of Whale Oil', which had been warehoused by another Salem vessel. After selling the mission three and a half tons of tobacco, they sailed to Sydney to relieve William Driver, who had more oil ready for shipping and was eager to return home. The Sydney operation was too successful to be closed down, 
however: Captain Charles Millett stayed behind to take charge of the store, with a clerk named Samuel Smith to keep the books.

The maintenance of the depôt in the Bay of Islands was more of a problem, as there was no government there and little law and order. The only moderating influence in the Bay was the mission - and relations with the mission had not improved. One who commented on this was Captain John Buttells Knights, who arrived on 25 March 1833, in command of the three-masted Salem schooner Spy. As usual, the immediate need was to fill his freshwater barrels, but because the Bay was full of shipping, there was a long queue at the public stream off Kororareka, where the 'noisy conduct' of the English whaling crews set 'a wretched example' to his men and where 'Rum, that curse to the Sailors', was readily available. ${ }^{23}$ Knowing it was useless to try the stream at Paihia, Knights set sail for 'another settlement about five miles up the River', dropping anchor 'about 2 miles below the Village called the Par'.

Within an hour, the ship was visited by the local chiefs, 'Chiva Chiva and Poo Murry' (Kiwi Kiwi and Pomare). Peaches, potatoes, pumpkins and cabbages arrived on board in exchange for tobacco, and next day Knights returned the visit by taking a boat to the pa. He went unarmed - a demonstration of courage that did not go unnoticed by the chiefs - and was shown into Kiwi Kiwi's house 'by a white Sailor who was residing among them'. The chief immediately asked for some medicine for his young wife, whose 'head was sick'. When Knights gave him pills, Kiwi Kiwi took one himself to ensure it was not poison and then gave the rest to his wife, who was soon cured: 'They came to visit me together, bringing me as a present two large Hogs and a quantity of vegetables and peaches; the chief said my name was now his name and his mine, and we must be great friends, and during my stay of three weeks I had not the least cause to complain.'

Knights waxed lyrical about the Maori people and their setting: 'I know of no spot on earth that presents such beautiful, romantic, and at times magnificent scenery as a sail up the Bay and the Kidde Kidde [Kerikeri] River. In truth Nature here scatters her blessings with an unsparing hand.' The natives did not take those blessings for granted, industriously raising 'large quantities of Indian corn, potatoes, squashes \&c., much of which they exchange, as well as Hogs, to the shipping \& the Missionaries for Tobacco, Blankets \& Muskets, calicoes \& prints'.

The same could not be said of the white residents: 'I am sorry to say that no difficulties took place while I was here that the resident whites and drunken sailors were not the prime movers of.' In Knights's estimation, the English residents of the Bay could be divided into two distinct classes: the missionaries and adventurers; and 'the bare faced villains'. As he confessed, he preferred the villains, 'because they act in character and seem what 
they in reality are... woe betide the Captain who allows the respect to the outward forms of religion to lull him into a belief that all are morally honest'. Knights also found the settlers addicted to malicious gossip. Instead of 'living in harmony and friendship and uniting together for common protection', they slandered each other at every opportunity, 'and the natives wonder that white men are so unkind to each other'.

On 20 April 1833 he set sail for Fiji, where he was lucky enough to procure a full cargo of processed 'beach de mer' from a Frenchman who had been left on shore to trade but whose ship had not returned. It had to be loaded in a hurry, because an American beachcomber, David Whippey, warned Knights the local tribe was plotting to attack and seize his ship. On 15 July he was back in his old anchorage in the Bay of Islands to re-stow his holds. In the depths of the southern winter, most of the time his was the only vessel in port, and while he was 'treated with the same respect and kindness' by the chiefs, Knights saw very little of them, 'the weather being so cold that the natives kept much in their huts'.

It was a miserable time. Because of the cold, the Maori traders would accept only blankets for hogs, so Knights had to sacrifice the covers from his own bed to feed his crew. Trading with the settlers for food emptied his stock of sugar, coffee, tea, and flour, and the fish did not bite. In short, he was cold and hungry: 'I will only add that I saw no reason to alter opinions before expressed relative to the missionaries, the British Settlers, or the Natives. ${ }^{24}$

Another Salem shipmaster to assess the Bay was John Eagleston, captain of the Emerald, who set out for the Pacific on 23 November 1833. As was usual, some teenaged apprentices from the Salem counting house went with him, in training for the trading duties they would fulfil later on. Two who kept discursive accounts were George N. Cheever and Warren Osborn. ${ }^{25}$

The passage to New Zealand was slow, but finally, on 18 April 1834, they raised the Three Kings, and Eagleston issued celebratory wine to the men and porter to the boys. He needed help to get into the Bay of Islands, as Cheever recorded on 21 April: 'Our Capt ${ }^{\mathrm{n}}$ boarded a small craft just ahead of us loaded with potatoes \&c., \& took from on board of her the only white man she had, who gave us a few directions \&c. ${ }^{, 26}$ Cheever elaborated:

About 4 PM (Tuesday) a gentleman (Capt ${ }^{\mathrm{n}}$ Powditch) boarded us thinking us to be a stranger and very politely offer ${ }^{\text {'d }}$ to pilot us up - which we of course as politely accepted - and at 8 having work ${ }^{\text {'d }}$ our way up amongst the shipping we were boarded by the capts of 7 or 8 English Whalers and the merchants and residents of the place - we came to anchor at about 9 - and were soon visited by the natives in considerable numbers. ${ }^{27}$ 
Captain Eagleston himself had no time to take note of the natives, merchants or residents, being busy entertaining the captains, many of whom were fellow Americans. As he wrote in his discursive journal, when he requested them to go into the cabin and make themselves at home, they did so with a vengeance, 'smoking 200 cigars, drinking lots of wine, and spinning long yarns about girls' ${ }^{28}$ Then they all repaired to one of the other ships, where they dined, wined, and spun tall tales until a very late hour, when they dispersed to their different vessels, 'most of them two sheets in the wind'.

Next day, Eagleston went on shore to deal with the local merchants, first meeting up with 'Messrs. Mair and Powditch, the first of these has an English wife which is quite pretty and several small children, which first saw daylight in the Bay of Islands, they all live in a small thatched house with two or three rooms in it'. ${ }^{29}$ Then he paid a call on an English chandler, James Reddy Clendon, finding he also had a wife and small children and lived in the same primitive style, though he had a fine house underway he expected to move into soon. Clendon, with his partner Stephenson, 'are the first in the place for business and character', the rest possessing 'no quality belonging to a gentleman'. Eagleston heartily agreed with Knights that the Bay was a strangely contentious place: 'All of these men reside some distance from each other, and carry on a heavy war of words, and never visit each other.' ${ }^{30}$

Captain John Eagleston was as unimpressed with the missionaries as Knights had been: '[They] live in the East side of the bay by themselves and up to their eyes in clover, I do not think them a very polite set as they did not show their wives when we visited them, nor were much pleasant to us. ${ }^{31}$ His young clerk, George Cheever, formed a similar opinion, reflecting: 'I believe on the whole the missionarys are not very desirous of the visits of strangers, particularly from the Shipping for they believe them to be evil dispos $^{\prime d} .{ }^{32}$

Cheever had visited the mission with his friend, Warren Osborn, on 23 April. Henry Williams noted that day: 'Two young men from the American ship which arrived yesterday [paid a call]. They were very polite and very communicative. ${ }^{33}$ Warren Osborn also described his visit to the mission:

Rev Mr Williams (the Superintendent) received us very politely and introduced us to Mr Chapman who had the care of the native school, they showed us a Bible in the New Zealand language and several native curiosities. They informed us of the present state of the mission, and of the condition of the other missionary settlements. Mr Williams walked out with us for an hour or two and showed us from a hill a fine view of the river and Bay. The soil about the settlements is poor and indeed 
it is in all the other parts that I have seen, but they told us it was better farther inland and that they had a fine farm. They have a few cattle but they do not thrive well there is so little for them to feed upon. They have a small native village near them and the inhabitants do not appear to be so vicious a set as those near the anchorage. I do not think that the Missionarys are fond of receiving the visits of strangers though I know not the reason. ${ }^{34}$

The chilly attitude of the mission was obvious to even the youngest and best intentioned. The missionaries, accustomed to dealing with whalers and their crews, whose shenanigans had helped make Kororareka 'the hell-hole of the Pacific', were yet to realise that the traders' much more serious aim was to create lasting business relationships. George Cheever, though the missionaries could not know it, agreed with their opinion of the troublemaking residents of Kororareka, writing that he believed their 'only occupation is selling grog. These whites I believe are chiefly runaways from Sidney ...' 35

The clerks and captain of the Emerald were not having a good experience in the Bay of Islands. In a report to the owner of the Emerald, Stephen Phillips, Captain Eagleston opined: 'I have a poor opinion of this place with regard to business. ${ }^{36}$ In his journal, he noted that he had procured some potatoes and hogs from the local chiefs, paying them in duck shot and a keg of powder, which was all that they would accept. ${ }^{37}$ However, it was cheaper than buying from the whites, who demanded $\$ 15$ a ton for potatoes. 'As to spars,' wrote George Cheever, 'there was no such thing to be had in the Bay. We might have obtain ${ }^{\text {d }}$ them if we had gone farther south and cut them ourselves, or here if we could have waited till one of the merchants or contractors had sent down the coast and cut them, either of which would have greatly detained us. Therefore we had no other alternative than going to sea without them.' ${ }^{38}$

Eagleston deemed the trade offered in the Bay for sale (apart from fresh provisions) 'hardly worth the notice of Americans': 'Its produce consists of Spars and Hemp in small quantities, which is bought up by the English and shipped to Sidney for England. ${ }^{39}$ The hemp was not cultivated, but grew wild, and was of excellent quality 'and makes beautiful rope, if the devils would turn their attention to the growing of it, it would soon become an article of great export'. ${ }^{40}$ On the other hand, it would be easy to sell a freight in the Bay, though payment would mostly be in bills drawn on the Board of Missions. He had been assured that these were as good as cash, so Eagleston went on to make 'a list of articles suitable for the Market', which could be brought in from the States - an inventory that included a great deal of tobacco, many kegs of nails, tar, pitch, cordage, calico, shirting, powder and shot, oars, 'country built Boats', oak planks, paint, '15 to 20 
Barrels good W[est] I[ndies] rum of good flavour', smaller quantities of gin and cognac, tea, flour, salt beef, Leghorn hats, Spanish wine, and cigars. ${ }^{41}$ A ship coming into the Bay of Islands from Manila or Canton could do well if the manifest included tea, gunpowder, 'sugar candy', nankeen cloth, shawls, handkerchiefs, clothes baskets, work boxes, preserved ginger, tea trays, wallpaper, sugar, coffee, and tea caddies - quite a commentary on the unavailability of even the most common luxuries in the Bay. ${ }^{42}$

The captains of the whalers in port were helpful as well as jovial, Eagleston noting in the letter to Phillips that they had given him 'a great deal of useful information relative to procuring Shell and Beche de Mer'. ${ }^{43}$ They also sold him $65 \mathrm{lb}$ of turtle shell and 500 sperm whale teeth, which, as young Cheever enthused, 'to us are as good as their weight in gold'. ${ }^{44}$ Eagleston paid the captains in tobacco, which was the main currency both on board ship and on shore. As Warren Osborn observed, 'both sexes of the natives are immoderately fond of Tobacco, they carry their pipes in holes bored in their ears' ${ }^{45}$ This was a relatively new development, as tobacco was not a favoured article of trade with the Maori until the late 1820 s, when pipe-smoking became highly fashionable. ${ }^{46}$

For the Americans, tobacco was an excellent currency, being cheap to obtain back in the States, and easily stockpiled in the depôt. However, this was one of the few conveniences of the Bay of Islands. George Cheever echoed the sentiments of his captain, writing: 'This part of New Zealand by no means equals the description I have read, and I was really rejoic'd when on Monday morning we weighed anchor for sea.' ${ }^{47}$

Before departing, however, the Salem skippers had found a quasi-formal representative to assist with the problem of safeguarding the store. This was the British Resident, James Busby, who according to Eagleston, 'lives on one of the islands by himself'. ${ }^{48}$ James Busby had arrived in May 1833 with a bagful of vine cuttings and eucalyptus tree seeds, his brief being the protection of respectable English settlers, the promotion of amicable MaoriEuropean relations, and the capture of runaway convicts. Unfortunately for him, the New South Wales government did not give him the constables and money he needed, and so the settlers, like the Maori people, regarded him with amusement or even open contempt, calling him 'a man-of-war without guns' ${ }^{49}$ As late as 1837 he was complaining that the missionaries acted precisely as if he were not there - 'even giving me information never seems to have entered their heads'. ${ }^{50}$

The Salem traders paid him more respect, considering him 'worthy and urbane' - his decanter of excellent port could have been a factor in the latter judgement. Captain Charles Millett of the Black Warrior affably agreed to do Busby a favour. The log mentions that on 8 April 1835, 'Mr Busby the British Resident sent two Natives aboard as passengers to Sydney'. ${ }^{51}$ The 
Salem traders proved useful in other ways: on 9 October 1835, Captain George Batchelder of the Charles Doggett called on Busby with important information, carrying two letters 'from a person who styles himself Charles Baron de Thierry Sovereign chief of New Zealand and King of Nukuhiva ... announcing his intention of establishing himself as an Independent Sovereign in this country, ${ }^{52}$

Busby moved at once to thwart de Thierry, assembling the chiefs of the northern tribes on 22 October 1835, and talking them into forming a confederation, signing a declaration of independence, and finalising their choice of a flag. James Reddy Clendon, a prohibitionist who was very much in favour of law and order, lent his support. In May 1836, when ten American whaling masters approached Clendon about the need for a US legal representative in the Bay of Islands, he convinced them to write a joint letter to the US State Department, asking for the appointment of a United States consul..$^{53}$

Clendon probably hoped that he would be selected. The role of consul would not only invest him with disciplinary powers but also grant him the monopoly of provisioning the American whalers. There were no restrictions about the nationality of consuls, it being usual to select them from the resident business community, and so every adult male European in the Bay of Islands was a candidate. Only Busby and Clendon were considered suitable, and though the Salem traders would have preferred the British Resident, Clendon got the job, as no US official was allowed to hold a concurrent appointment with another government. On 12 October 1838 John Forsyth, the US Secretary of State, handed the consular documents (Clendon's commission, a book of general instructions, and a bond form) to Nantucket shipping merchant Frederick C. Sanford, who carried them to the Bay of Islands on the whaling ship Nantucket. He delivered them to Clendon on 25 May 1839. A US flag was not included, so Sanford gave him the ship's ensign, which Clendon hoisted to a pole on the foreshore of his new property at Flagstaff Hill. ${ }^{54}$

After arriving in Nantucket on 24 September 1839, Sanford wrote to the Secretary of State that law, order and government in the Bay of Islands 'was exceedingly loose', but he was certain Mr. Clendon, 'a fine man', would carry out his duties 'to the full satisfaction of the department'. ${ }^{55}$ The Salem merchant N.L. Rogers certainly believed this, sending out three vessels, Tybee, Nereus and Shepherdess, with rum to be consigned into the care of the consul and stored in bond until removal for shipping elsewhere. ${ }^{56}$ The Nereus, Captain Chapman, dropped anchor in the Bay on 13 October 1840, to find the Tybee, captained by Millett, discharging 22 casks of rum. The crew of the Nereus broke out 40 casks of rum on 20 October and 39 more the following day. ${ }^{57}$ During the unloading the Shepherdess, Captain Hooper, 
arrived and discharged her cargo, completing a consignment of 158 casks, holding a total of 18,647 gallons. Then, like the Tybee and the Nereus, the Shepherdess sailed, having left her valuable cargo in presumably trustworthy hands. However, while Clendon was sending regular despatches (assisted by his clerk, an English ex-convict by the name of Charles Berry Waetford, and an American settler, Captain William Mayhew) and supplying the whale ships in efficient fashion (to his personal profit), his failure to give 'full satisfaction' was spectacular. ${ }^{58}$

James Reddy Clendon's nemesis was Captain Charles Wilkes of the US Exploring Expedition. On 30 March 1840 the flagship Vincennes dropped anchor 'in the Kawa-Kawa river, opposite the residence of Mr. Clendon, the American consul'. ${ }^{59}$ Wilkes went on shore to find that the chiefs had signed a Treaty the previous month, "which was in reality nothing more or less than a cession of their lands, authority, and persons, to Queen Victoria', and that Clendon 'an Englishman acting as American consul' had promoted it:

The influence of Mr. Clendon, arising from his position as the representative of the United States, was among the most efficient means by which the assent ... was obtained. The natives placed much confidence in him, believing him to be disinterested. He became a witness to the document, and informed me, when speaking of the transaction, that it was entirely through his influence that the treaty was signed. ${ }^{60}$

Not only was the Treaty 'a disastrous circumstance for the natives, which will seal their doom, and make them the prey of the hosts of adventurers who are flocking in from all parts', Wilkes thundered, but it involved levies and imposts that were 'destructive to [American] commercial pursuits, while they offer the most marked protection to those of British subjects!' ${ }^{1}$ He later elaborated: 'Americans are not permitted to hold property, and, in consequence, their whaling establishments on shore must either be broken up altogether, or transferred to other places.... Thus have our citizens been deprived of a fishery yielding about three hundred thousand dollars annually in oil.' Yet the US consul had not only advised the chiefs to sign but had signed it himself, as a witness. When Wilkes angrily quizzed Clendon about this gross disloyalty, the unrepentant chandler retorted that he "had acted as a private citizen' in the matter, not as the US consul. ${ }^{62}$

The US consul in Sydney, James Hartwell Williams, was equally concerned. On 1 August 1840 he wrote to the Secretary of State that British colonial law in New Zealand was 'destructive to [American] commercial pursuits while they offer the most marked protection to those of British subjects'. ${ }^{63}$ This analysis, with Wilkes' fiery report, led to much alarm in the corridors of Washington. When the British first proposed annexing the country, there were a great many more American vessels in New Zealand 
than British ones. Assuming that their citizens would get special status, the US government had failed to register a complaint, and now it seemed they had been too trusting. ${ }^{64}$

The American minister in London, Andrew Stevenson, was instructed to communicate the State Department's concern that no regulations should be published that were prejudicial to American commerce. However, despite a strong letter to Lord Palmerston urging 'the rights and customary privileges' of American shipping in New Zealand, the British Foreign Office did not bother to reply until 23 March $1841 .{ }^{65}$ The American minister (now Edward Everett) was then curtly informed that the rights and privileges that had been assumed with the signing of the Treaty were solely for the benefit of British subjects. ${ }^{66}$

The Secretary of State demanded Clendon's resignation in a curt communication dated 26 April 1841. Forewarned, however, Clendon wrote a face-saving letter of resignation dated six days earlier. Recommending Captain William Mayhew, 'a Citizen of the United States, and a Merchant of the highest respectability', to stand in as vice-consul, Clendon then headed off to Auckland (now the seat of government), and a place on the Legislative Council. ${ }^{67}$

Whaling master William Mayhew was apparently well qualified. From the island of Martha's Vineyard, Massachusetts, in 1834 he had commanded the first of two voyages to New Zealand for the Rhode Island firm of Burr and Smith. In 1837 he had settled in the Bay, investing in land - a farm at the Bay of Islands and Tahoramaurea Island (Brown's Island, off Kapiti) near Wellington, where he had a whaling station - and also in goods he imported from Rhode Island on the 365-ton schooner Henry Tuke, sending back oil in exchange. Like Clendon himself, Mayhew was one of the eight original directors of the New Zealand Banking Company, which opened New Zealand's first bank in September 1840, in Kororareka, and he had already assisted Clendon in the consular work. Mayhew's situation appeared solid, but in reality he was in deep financial trouble, embroiled in a struggle to keep the British from confiscating his property - quite a contrast to Clendon, who had been awarded 10,000 acres of land 'as he may choose to select in the neighbourhood of Auckland', plus an unspecified amount of cash, in exchange for 200 acres at Okaito (Russell). ${ }^{68}$

In addition, Mayhew had no idea that Clendon had resigned and that in accepting the post, he would be the only person responsible for American interests in rapidly deteriorating circumstances. However his backers, ship owners Burr and Smith, who fully understood the commercial potential of the consulate, wrote letters of support to Senator James Simmons and their congressman, R.B. Cranston, with the aim of getting their man the job of full consul - a project doomed to failure by international politics. ${ }^{69}$ 
On 21 February 1842 Mayhew confirmed the State Department's worst prognostications in a long impassioned letter, complaining bitterly that the British administrators 'have now assumed the entire Sovereignty of these Islands and have enacted laws and levied Imposts peculiarly harassing to our Citizens and most destructive to their Commercial pursuits, whilst they offer the most marked protection to their own commerce'. ${ }^{70}$ An Act had been passed by the Legislative Council that imposed duties 'from Ten to Five Hundred per centum' on American goods - even on goods that had been imported prior to the passing of the discriminatory law but were still held by the consulate. ${ }^{71}$

The particular goods Mayhew had in mind were the 18,647 gallons of rum that the captains of the Tybee, Nereus, and Shepherdess had deposited into bond in September and October 1840. In March 1841 Captain Cross, master of the Salem trader Lydia, called at the consulate with the disturbing news that duties would be laid starting the following month. Mayhew, armed with the documents the captains of the Tybee, Nereus, and Shepherdess had signed and Clendon had witnessed, boarded the Lydia for Auckland, to lay his case before the government. Halfway there they encountered the British warship HMS Favorite, whose commander, Captain Dunlop, informed Cross he was headed for the Bay of Islands to seize a stock of 'contraband' rum left there by Salem traders. Mayhew demanded passage on the man-of-war so he could return to the Bay and try to save US property, but Dunlop refused. ${ }^{72}$

The Lydia turned back, but the winds were against them, and they arrived too late to prevent the assessment of customs duty at the rate of five shillings per gallon - a total of over $\$ 22,000$ on rum that was worth less than $\$ 6000$ in New England. In August, when Charles Mugford, now captain of the Rogers ship Grotius, arrived to take the rum away, it was to find that Mayhew had got rid of it the best he could by selling it locally for one shilling, sixpence per gallon. The Vineyarder did not divulge the name of the buyer but conveyed to Mugford that someone in the lower ranks of the administration was raking in a profit. Furthermore, as it had been purchased on credit, he doubted that the bill would ever be paid. Mugford demanded details, but Mayhew told him it was pointless to complain. As Mugford commented to N.L. Rogers in a heavily underlined letter, 'you will understand why he thinks so, when you learn that the United States Consul is one of the Legislative Council, and helped to pass the Act ${ }^{\prime} .^{3}$

Mayhew had already written to Nathaniel Rogers, who referred the matter to his Massachusetts representative, the Hon. Leverett Saltonstall. As Rogers dryly commented, the payment of customs duties on that scale was quite out of the question, as it would 'drink up' all the profits, and he urged the congressman to take it up with the State Department. Saltonstall did more 
than that: the complaint went all the way to Whitehall. There, the current American minister to London, Edward Everett, went through the files to build up a case - and found New Zealand under the heading of 'Independent Pacific Islands' in the official list of representatives abroad.

This was an era of great European interest in colonising 'independent Pacific Islands'. The French had a firm hold on Tahiti; the Germans were very strong in Samoa; and now the British had New Zealand. On 30 November 1842 Everett wrote a confidential despatch to the new Secretary of State, Daniel Webster, suggesting that official US recognition of British government in New Zealand should be withheld to protect American interests in the Hawaiian Islands, a policy that was adopted. ${ }^{74}$

The refusal of recognition had repercussions for William Mayhew, because the colonial government retaliated by refusing to issue an exequatur (the certificate that gave him official recognition). Meanwhile, the Salem merchants were lobbying for a replacement for James Reddy Clendon (who they still believed to be the US consul), with the result that on 10 March 1842 President Tyler appointed John Brown Williams - the young man who had been the supercargo of the Salem trader Tybee - to the post. ${ }^{75}$

John Brown Williams arrived in the Bay in December 1842, to find the settlement greatly changed from his visit ten years earlier: the shingle bank with a few shacks and trading sheds was now a sprawling settlement of about 200 renegade whites. There were innumerable grog-shops - those 'lowest depths of hell!' - and drunken sailors shambled from one to another, creating mayhem in the streets. ${ }^{76}$ The Yankee whalers were nothing better than floating castles of prostitution, swarming with women who had been sent on board by certain white residents of Kororareka - 'a covetous and malicious people, malignant whisperers, full of envy and every evil' - who abused the positions of authority given to them by the new administration. ${ }^{77}$ The reason the British had recently shifted the seat of government from Kororareka to Auckland, reckoned Williams, was the lack of honest, reliable, and respectable people in the village. One of the few exceptions was Busby, 'the ex British Resident', that 'worthy and urbane Gent', who still lived on his property at Waitangi, though he visited Sydney often, trying to validate his own land claims. ${ }^{78}$

Williams also approved of the Maori residents, rating them 'an extraordinarily temperate people' because they disliked the smell and taste of liquor. The British had taken advantage of their ignorance, indolence and simplicity when they had enticed them to sign the Treaty - 'by fair speeches and fair words they have been deceived'. Not only had the natives been 'rob'd of their country' but the Europeans had set a bad example - 'If the Europeans do not regard the laws, why should the New Zealander be scourged for not obeying what he does not rightly understand?'79 
John Williams was more guarded in his opinion of his predecessors. While Captain Mayhew treated him 'with that civility and respect due to me as US consul', in his candid opinion the clerks he had inherited from Clendon and Mayhew - ex-seaman Henry Green Smith of Rhode Island and English ex-convict Charles Berry Waetford - were untrustworthy rogues. Since arriving in New Zealand, Waetford, born 'Charles Walford' in Morden, Lancashire, in 1808 and transported for life at the age of fifteen, had married Jane Ini te Hini Clark and learned to speak fluent Maori. In May 1843 he launched a smooth-hulled 68-ton schooner with the whimsical name I Don't Know, which he sent to Sydney and the South Pacific, ostensibly on trading voyages, though the administration certainly believed that he was supplying the Bay of Islands Maori 'rebels', and that Henry Green Smith was actively assisting him. ${ }^{80}$

However, if they were indeed arming Maori dissidents, John Brown Williams could have felt a sneaking sympathy, for relations between the consulate and the administration were at a very low ebb. On 12 February 1844 , Williams wrote to the Secretary of State, ostensibly to urge him to send a frigate to impress the colonials with American naval might but also to ask him to have Fiji included in the consular jurisdiction of New Zealand, claiming that the British were 'casting a longing eye' on those islands. Almost as an afterthought, he announced that he was re-appointing Mayhew vice-consul in the Bay and was coming home on the Nile of New Bedford, on the grounds of 'ill health', enclosing a medical certificate that he suffered from dyspepsia. However, he had several other reasons for quitting the post. ${ }^{81}$

First, he had still not been formally recognised as the US consul. John Brown Williams was a pawn in a game of political tit-for-tat: the US government had clung to their stance that though Americans were entitled 'to very liberal treatment' they weren't getting it, so Washington had refused to acknowledge the British government in New Zealand; accordingly, the New Zealand administrators had refused to recognise their man. Second, as the best local appointment Williams could hope for was US commercial agent for the Bay of Islands (which did not need an exequatur), he had decided to try for the post of commercial agent in Fiji. Attracted by the brighter prospects there of making a mercantile fortune, he planned to run the Bay of Islands agency from afar. Now, he was going back to Massachusetts to arrange with the export-import firm of Breed and Huse for cargoes of Yankee manufactures - including guns and powder - to be exchanged in the Pacific for bêche de mer, pearl-shell, and coconut oil. ${ }^{82}$

William Mayhew was in Sydney at the time and remained unaware of his re-appointment until late March 1844, when he returned to discover that Waetford and Smith were looking after the consulate. Mayhew neither 
needed nor wanted the distraction. Just the previous month he had written to Salem trader Charles Millet, complaining: 'Times get worse here every day as the Government proceeds - no money - no ships - no business - no person certain of their lands unless they have purchased from Government in the pet town of Auckland, consequently a general stagnation prevails. ${ }^{83}$ He was on the verge of losing both farm and whaling station; on May 15, after reassigning his lease to Henry Green Smith, he quitted the country in a hurry, leaving behind his many debts. ${ }^{84}$

A month later, James Busby left in equally dramatic circumstances. On 6 May 1844, the Salem whaleship Elizabeth arrived to carry out urgent repairs, and when Captain Isaac G. Hedge paid a call at Waitangi, he found that Busby was in dire financial straits, having been unable to prove his claims. The Elizabeth was in such a leaky state she had to be beached for repairs, and by the time she was floating again, Busby was on the verge of being jailed for bankruptcy. Hedge was pleased to assist the man who had done so many favours for the Salem skippers: he loaded a cargo of thirty tons of kauri gum on Busby's behalf, and preparations were made to spirit the man himself away. On the brink of their departure on 4 June, however, Norton recorded in his log: 'An officer from Shore came on board and put an attachment upon the property of Mr Busby and we are consequently detained until farther orders. Ship in possession of a constable. Rule Britannia! So Ends. ${ }^{85}$ However, all ended well. Next day, while the ship was in the stream preparing to raise sail, Busby boarded from a boat, and the Elizabeth transported him safely to the States, where the sale of the gum retrieved his fortunes. ${ }^{86}$

The departure of Mayhew and Busby left Henry Green Smith and Charles Berry Waetford in charge of the office and free to their own devices, which reputedly included giving the Maori chiefs little US flags to fly at the prows of their canoes. Over the next ten months relationships between the British administration and the Bay of Islands Maori - led by Hone Heke, who had been the first chief to sign the Treaty, but who had been greatly disillusioned since - deteriorated drastically. The British flagpole was chopped down not just once, but three times, in a symbolic expression of revolt. According to gossip, the American whaling crews who were in port cheered him on; the Stars and Stripes was spared to flutter bravely on the beach. Infuriated, the local police magistrate sent a stiff message to Smith informing him that the 'hoisting of any National Flag' save that of Great Britain was prohibited.$^{87}$ 'I beg to inquire by what authority', wrote Henry Green Smith with distinct hauteur. ${ }^{88}$ 'By the directions of His Excellency, The Governor, there being no Consul at this port', retorted the magistrate. ${ }^{89}$

Finally, on 10 March 1845, a Maori war party commanded by Hone Heke attacked Kororareka and burned most of it to the ground. Smith joined in 
the looting and then fled on the Sag Harbor whale ship American with a load of purloined copper..$^{90}$ Waetford loaded the consular archives on the I Don't Know and sailed to Auckland in the company of HMS Hazard, the English whale ship Matilda, the colonial schooner Dolphin, and under the protection of the US Navy corvette St. Louis. Washington had at last paid heed to John Williams's request for a US naval presence in the South Pacific. When the town had been attacked, the St. Louis had been lying at anchor in the Bay: her commander, Captain Isaac McKeever, had rescued a large number of women and children, and now he was carrying them to safety in Auckland. ${ }^{91}$

Accordingly, a high-ranking US naval officer witnessed that the surveying inspector for the Port of Auckland boarded the I Don't Know and charged Charles Berry Waetford with incitement of riot and larceny. ${ }^{92}$ The Englishman languished in a cell until 2 June, but then, having demanded a jury of his peers, he went on trial and was acquitted. ${ }^{93}$ The captain of the I Don't Know, Thomas Thompson, resumed command of the schooner and presented an audacious bill to the administration - for two glass panes in the skylight broken when the vessel had been boarded, three tons of firewood used up by the constables who had lived on the ship, five yards of canvas gnawed by rats after the sails had been taken ashore to make sure the schooner did not slip away, and three gallons of brandy that had somehow leaked from the keg on the cabin table. ${ }^{94}$ Instructed the Colonial Secretary in a furiously underlined note to the Marine Surveyor: 'Direct the Superintendent of Public Works to replace the broken glasses - and one ton of fuel. I will allow nothing more. The escape of these people is a Disgrace to Auckland. ${ }^{95}$

The schooner escaped altogether on 10 June, clearing for Wellington, where Waetford found John Brown Williams on the Breed and Huse brig Falco, having just arrived from Adelaide, South Australia. Breed and Huse had agreed to Williams's plan, and the State Department had awarded him a commercial agency in Fiji. ${ }^{96}$

Williams took the archives on board the Falco and made sail for Auckland to collect a load of kauri gum and flax stockpiled by his business partner there, Joel Polack. However, the Falco was stranded by a storm off the east coast. A gang of white whalers ('composed of the greatest ruffians in existence', according to the New Zealander) boarded the wreck and with a party of Maori looted the cargo, damaging the ship so badly she was a write-off. ${ }^{97}$ Williams had to take refuge in the house of a settler and even then was threatened by some of the Europeans who had every intention, they declared, 'of drinking his blood'. ${ }^{98}$

On September 10 he arrived in Auckland in the schooner Uncle Sam, along with the captain and crew of the Falco, and filed a suit on the New Zealand government for the value of what he had lost, citing 'piracy, plunder, 
and destruction of both vessel and cargo, and the insult to me as consul of the United States'. Instead of paying up, however, the administration accused him of inciting Maori riot, and being indirectly responsible for the burning of Kororareka..$^{99}$

Unbeknownst to Williams, the British authorities had just received intelligence from George Grey, the Governor of South Australia, that the Falco had carried 7000 pounds of gunpowder on board when she left Adelaide, together with fifteen cases of muskets, the whole lot consigned to John Brown Williams, 'who had assumed the character of Consul to the United States of America at the Bay of Islands'. According to intelligence, the arms and powder had been ordered 'by an individual named Mayhew, who had acted in the same capacity to incite the Natives'. ${ }^{100}$

Williams was summoned to a very serious interview with Governor Fitzroy, followed by a banquet, which he attended in the dress uniform of a captain in the US Navy, with his hair freshly dyed. By the time he had cleared his name by proving he had been in Adelaide when Kororareka had burned (and had been scolded by Fitzroy for being away from the Bay at such a critical time), he was more than ready to beat a retreat to Fiji. Before departing, Williams sent off his stockpile of gum and flax on the Breed and Huse ship Robert Pulsford, 'the first ever loaded with a full cargo of New Zealand produce for the United States'. He also declared Auckland the site of what he insisted on calling the US consulate, which to the locals appeared no more than a commercial agency. ${ }^{101}$

The man he put in charge of the Auckland office was a local American speculator, Edward C. Breed, a scion of Breed and Huse. The job was by no means a sinecure. Within days Breed received a letter from Charles Berry Waetford, saying that the writer wished to claim redress on behalf of 'an American citizen whose representative I am' - William Mayhew - but, as he had heard that John Brown Williams was not the legal US representative, he did not know to whom he should apply. Breed passed this on to Williams, who tartly advised Waetford to take up the matter with the State Department in Washington, 'as Captain McKeever of the U.S.S of War St. Louis will have made his report on the subject'. ${ }^{102}$

In September 1845 Williams returned to Auckland to deal with an angry communication from the State Department informing him that the British Government in Whitehall had filed a formal complaint that he and his agents had incited rebellion in the Bay. Sir George Grey, who had been the Governor of South Australia when the Falco had called at Adelaide with that infamous cargo of muskets and powder, was now the Governor of New Zealand. Sending a copy of his original report to Whitehall, Sir George had suggested that a representation should be made to the US government - exactly what happened, even though Lord Aberdeen did not 
think the evidence 'sufficiently explicit and detailed' to merit an international incident. ${ }^{103}$ The US Secretary of State wrote Williams frostily that 'your instructions from the Department direct you scrupulously to abstain from all participation' in the political concerns of the host country. ${ }^{104}$

Then Edward Breed created yet another complication by leaving Auckland to return to the States. In July 1846 Williams assigned the charge of the Auckland 'consulate' to his business partner, Joel Polack, and sailed for Fiji again, but without appointing anyone to take over the Bay of Islands office. ${ }^{105}$ Polack had to face a stiff letter from the British administration demanding to know the names of the Americans who had incited the Kororareka riot. Then came the wreck of the Martha's Vineyard whale ship Delphos at the Bay of Islands, which left all the officers and crew destitute. ${ }^{106}$ After returning to New Bedford they complained to the papers about the lack of help, saying the man who was supposed to be the US consul had 'gone to the Fijis to sell rum' instead of attending to his proper duties. ${ }^{107}$

The problem of desertion in the Bay was also pressing: Williams recording a year earlier that at any given moment there were up to 120 unemployed American seamen wandering about the village, now called Russell. 'Many are talented men', he wrote, 'and with a proper field for them would be shining lights in society' ${ }^{108}$ Instead, they were at a loose end and getting into trouble. Like Breed, Polack tried to cope from afar but with equally poor success. The matter came to a crux in December 1846, after six crew of the whale ship Nile tried to set fire to the ship. When Captain Nathaniel Hamlin sent an urgent message to Polack, he was advised to bring the Nile to Auckland or apply for help to the local police magistrate - James Reddy Clendon, the man who had sold out to the British. The whaling master sent a furious complaint to the State Department, dumped the six men in Russell, and sailed away. ${ }^{109}$

Two more years elapsed and more lobbying by Hamlin's equally exasperated brother shipmasters - Captain William Potter of the Flora, for instance, complained that when his vessel struck on a rock in the Bay, there was "no consul to turn to and no assistance from the authorities'. ${ }^{110}$ John Brown Williams finally returned to Auckland in April 1848, having received a curt summons from Washington. First, he fired Polack, blaming him for the bad press he had received, and then selected another Briton (though one who had resided some years in the United States), Robert Appleyard Fitzgerald, to take Polack's place in the Auckland office. ${ }^{111}$

After that, Williams went to the Bay of Islands to find someone suitable to man a sub-agency. Ex-British Resident James Busby, who had returned from his hasty retreat to New England, was his choice. Williams dashed off a brief affidavit to the State Department, then sailed back to Fiji, leaving 
Busby to set up the office on his own, without any accoutrements such as flags, archives, or office stationery. ${ }^{112}$

Over the next few months, Fitzgerald resigned the Auckland post, to be followed in rapid succession by two others. All three found the job nothing but a burden. Not only did they get little in the way of fees, as few American vessels dropped anchor in that port, but the colonial administration refused to acknowledge their status. Meanwhile, James Busby worked on in the Bay, assisting an average of 25 American shipmasters a year. He had to administer the post from his own house on the Waitangi River, presenting yet another difficulty. It was still against colonial law for the US flag to be publicly flown in New Zealand, so the captains had to track down his office by asking the locals for directions. Altogether, despite John Brown Williams's affidavit and the backing of his influential friends in Salem, Busby's position was shaky. Then, in December 1850, he discovered how vulnerable he was.

Busby had fallen ill during a visit to New South Wales and so was absent when the first whaling ship of the season, the Mary of New Bedford, captained by James Henry, came into the Bay of Islands to provision and stow water. Charles Berry Waetford clambered on board, informed Captain Henry that he was the consul, took possession of the ship's papers, and charged the usual consular fee. He thumbed his nose at the local administration, too, spreading 'an American Ensign on the beach before his door' and announcing to the world that by morning the flag would be flying on the breeze, 'when he would see who would dare to pull it down'. By late February, when Busby returned to the Bay, twelve shipmasters had deposited their papers with Waetford and had signed 'a Memorial to the United States Government representing the want of a Consul at this port, and recommending the said C.B. Waitford for the office' - evidence, according to Busby, of 'the extraordinary ascendancy which the said C.B. Waitford appears to be capable of acquiring of the minds of masters of whaling ships'. Even the sick seamen left in Busby's care were talked into writing complaints. ${ }^{113}$

It was ridiculous that he should be in this position, Busby exclaimed; his job would be so much easier if he had an official flag (which he was allowed to fly), and Williams (though in Fiji) had an exequatur. Neither was forthcoming. Instead, the struggle for control of the consulate dragged on, with Waetford in a position of power because he had been appointed sub-collector of customs at Russell. With supreme irony, one of his official responsibilities was to enforce a newly enacted rule - that American whaling ship masters trading spirits, tobacco, powder, shot, or "warlike stores of any kind' in the Bay of Islands were liable to the due process of British law. ${ }^{114}$ 


\section{Journal of New Zealand Studies}

Finally, the US government and the British sorted out their dispute. Under the British-American Claims Convention of 1853, the US formally claimed $\$ 9,565.63$ on behalf of N.L. Rogers and Bros., of Salem, and after some dickering Rogers received \$7,676.96. The quarrel over, recognition of British sovereignty in New Zealand was duly registered in Washington. Waetford then renewed his request for appointment as the US consul in the Bay of Islands, which triggered Washington into doing something about the strange situation. ${ }^{115}$

In 1855 the Secretary of State ordered John Brown Williams - who had not come near New Zealand since 1848 - to make his choice between New Zealand and Fiji. Williams decided on Fiji (where he died of dysentery just five years later). Busby was put in charge of the office while the State Department looked for a replacement, and the colourful and chaotic story of Salem adventurers in New Zealand was finally brought to an end. ${ }^{116}$

1 Hannah and Eliza logbook, Nantucket Historical Association, Pacific Manuscripts Bureau Microfilms (PMB) 377, 397, Alexander Turnbull Library (ATL), Wellington. Salem had a very small whaling fleet - only one, brig Nancy, in 1831, a number that rose to 7 by 1833. Frances Diane Robotti, Whaling and Old Salem, New York, 1962, pp.57-58.

2 Rhys Richards, 'United States Trade with China 1784-1814', in American Neptune (AN), 54, special supplement (1994), pp.8-10; R.G. Albion, W.A. Baker and B.W. Labaree, New England and the Sea, Middletown, Ct., 1972, pp.56-60.

3 George Granville Putnam, Salem Vessels and their Voyages, 4 vols, Salem, 1924-1925, II, pp.1-18, 50-51, 132.

4 The silver Spanish dollar, which had the same value as the American dollar, was legal tender in the United States at the time and was used as currency throughout the Pacific and Orient. A picul was equal to133.33lb or $60.48 \mathrm{~kg}$.

5 Driver, letter to editor, Salem Register, 25 June 1883, quoted in Putnam, IV, p.96. A quintal is equivalent to $100 \mathrm{lb}$ or $45.36 \mathrm{~kg}$.

6 Putnam, IV, pp.40, 133-35, 159.

7 Driver to nephew, 24 March 1877, PMB 039, Peabody Essex Museum (PEM), Salem.

8 Rev. Henry Williams, journal entry 5 June 1831, in Lawrence M. Rogers, ed., The Early Journals of Henry Williams, Senior Missionary in New Zealand of the Church Missionary Society 1826-40, Christchurch, 1961, p.180.

9 Ibid.

10 Driver to nephew, 24 March 1877.

11 Henry Williams, journal entry 5 June 1831.

12 Ibid, 19 July 1831, p.183.

13 Ibid, 20 July 1831, p.183.

14 Ibid

15 Ibid, 21 July 1831, p.184.

16 Driver, letter to editor, Salem Register, 10 June 1883, quoted in Putnam, IV, p.95.

17 Driver charged the Bounty people a token $\$ 500$ and was rewarded with curious gifts manufactured from bits of the famous mutiny-ship and a letter of recognition signed by George H. Nobbs and three other colonists. Nobbs, Arthur (his mark) Quintal, John 


\section{The Salem Connection}

Buffett, and John Evans to Driver, 3 September 1831, William Driver Papers, PMB 780, Tennessee State Library and Archives (TSLA), Nashville; Ralph D. Paine, Ships and Sailors of Old Salem, London, 1924, pp.375 and facing page (Paine incorrectly dates the letter 1830).

18 The Fijian weapons were deposited with the East India Society, which became the Peabody Essex Museum. Putnam, IV, p.43.

19 Putnam, IV, p.67 (The location of the warehousing is not given.). Tybee logbook, 1832-1833, PMB 206, PEM.

20 Nigel Wace and Bessie Lovett, Yankee Maritime Activities and the Early History of Australia, Canberra, 1973, p.47; Putnam, IV, p.95.

21 Rogers, Black Warrior, logbook, 10 October 1834, PMB 206, PEM.

22 Mulford, Black Warrior, logbook, Jan. 22, 27, 1835, PMB 206, PEM; the price of the muskets is itemised in the voyage of the Emerald that same year.

23 John B. Knights, discursive undated sea-letter on schooner Spy, relevant matter beginning “... arrived at the Bay of Islands, New Zealand, on the 25th of March 1833", PMB 220, PEM. All subsequent quotations from Knights are from this document.

24 The quotations from Knights end here. Knights sailed 11 August 1833 to Manila, where he sold the cargo and also the ship, being "totally unfit for the business intended", and on 28 January 1834 took passage to New York on ship Moscow, Captain Rushworth.

25 George N. Cheever, Emerald journal, 1833-1834, PMB 223, PEM; Warren Osborn, Emerald journal, 1833-1834, PMB 223, PEM.

26 Cheever, journal entry Monday 21 April 1834.

27 Ibid. The nautical day began and ended at noon, so while Cheever noted "4 PM (Tuesday)", the day was still, in fact, Monday 21 April 1834.

28 John Eagleston, Emerald, 8-page discursive journal entry labelled in the margin, "April [1834], At anchor in the Bay of Islands.” PMB 223, PEM.

29 Ibid, p.2.

30 Ibid, p.2.

31 Ibid, p.3.

32 Cheever, Emerald, 2-page description of the Bay of Islands, following arrival on 21 April 1834, p.2. PMB 223, PEM

33 Henry Williams journal entry 23 April 1834, Journal, p. 369.

34 Warren Osborn, Emerald, 3-page description of time in the Bay of Islands, initially dated Tuesday, April 22, pp.1-2. PMB 223, PEM.

35 Cheever, Emerald, 2-page description following 21 April 1834, p.2.

36 Eagleston to Phillips, 27 April 1834, PMB 223, PEM.

37 Eagleston, Emerald, discursive journal, p.3.

38 Cheever, 2-page description of Bay, p.2.

39 Eagleston, discursive journal, p.6.

40 Ibid.

41 Ibid, pp.6-7.

42 Ibid, p.7.

43 Eagleston to Phillips, 27 April 1834.

44 Cheever, Emerald, 2-page description of time in the Bay, p.2.

45 Osborn, Emerald, 3-page description of time in the Bay, p.3.

46 R.P. Hargreaves, From Beads to Banknotes, Dunedin, 1972, pp.16-17. 


\section{Journal of New Zealand Studies}

47 Cheever, Emerald, 2-page description of the Bay, p.2.

48 Eagleston, discursive journal, p.3. Interestingly, in view of the date (April 1834), he added: 'The Natives having but lately chosen there Flag which is English union with American stripes.'

49 Reeves, William Pember. The Long White Cloud: Ao Tea Roa. London, 1924. p.131.

50 Claudia Orange, 'Busby, James', in The Dictionary of New Zealand Biography (DNZB), updated 22 June 2007. Accessed 28 January 2009 at: www.dnzb.govt.nz. The complaint about the missionaries is quoted in Eric Ramsden, Busby of Waitangi: H.M.'s Resident at New Zealand 1833-40, Wellington, 1942, p.177.

51 Black Warrior, Capt. Charles Millett, logbook 7-8 April 1835. PMB 206, PEM.

52 James Busby to Alexander Ellick, 23 March 1835 (arrival of Black Warrior), Busby Papers, MS Papers 0347, ATL; James Busby to Alexander Ellick, 6 April 1835 (native lads sent as labour, must be treated well, 'for they are not the people to bear knocking about'), ibid.

53 Busby to Colonial Secretary, 10 October 1835, Busby Papers, MS Papers 0347:0068, ATL; Jack Lee, 'Clendon, James Reddy', DNZB, updated 16 December 2003, accessed 28 January 2009 at: www.dnzb.govt.nz; Lewis Wasserman, 'The United States and New Zealand', PhD thesis, University of California (Los Angeles), 1948, p.42.

54 Rhoda Elizabeth Hackler, 'Our Men in the Pacific: A Chronicle of United States Consular Officers in Seven Ports in the Pacific Islands and Australasia During the Nineteenth Century', PhD thesis, University of Hawaii, 1978, pp.170-1.

55 Sanford letter, written from Nantucket, 24 September 1839, United States Consulate (New Zealand), US Despatches, Micro-MS-0934-01, ATL (hereafter US Despatches).

56 Nathaniel L. Rogers to Secretary of State, 30 March 1844, Governor [record group] (G) 1/11, National Archives (NA), Wellington.

57 Capt. Chapman, Nereus, PMB 210, PEM.

58 The identity of Clendon's clerk is documented by a report signed 'Ch. Berry Waetford, Acting', 30 June 1840, Rhode Island Historical Society, Providence, while the Rogers letter states that Mayhew signed for the rum as Clendon's representative. Hackler, pp.171-5.

59 Charles Wilkes, Narrative of the United States Exploring Expedition during the Years 1838, 1839, 1840, 1841, 1842, 5 vols, Philadephia, 1845, II, pp.370.

60 Ibid, p.376.

61 Ibid, p.377.

62 Ibid, pp.377-79.

63 Hackler, p.175.

64 Stanley to Fitzroy, 20 July 1844, G 1/11, NA; Hackler, p.175; Under-Secretary Stephen to Backhouse, 15 February 1841, Historical Records of Australia, Series One, XXI, pp.268-9.

65 Wasserman, pp.56-58. The Massachusetts representative who lobbied US Secretary of State Forsyth was the Hon. Leverett Saltonstall of Salem. See Leverett Saltonstall, The Papers of Leverett Saltonstall, 1816-1845, eds Robert E. Moody and Marjorie F. Gutheim, (Collections of the Massachusetts Historical Society, vols 82-86), Boston, 1978-1992, vols 82-84. The Society holds both the Saltonstall and the Edward Everett papers.

66 Wasserman, pp.56-58.

67 Wasserman, pp.52-55; Hackler, p.175.

68 Hackler, p.176; New Zealand Advertiser (NZA), 17 September 1840; Bay of Islands Gazette (BIG), 17 September 1840 (notice of commencement of New Zealand Banking 


\section{The Salem Connection}

Co.); manifests of the Henry Tuke voyages, held at the Rhode Island Historical Society, provide an interesting record of the state of trade at the time; New Zealand Gazette (NZG) 31 July 1841; Wellington Spectator, 31 July 1841 (Clendon's reward).

69 Hackler, pp.176-7.

70 Mayhew to Secretary, 21 February 1842, US Despatches.

71 Ibid.

72 Rogers to Secretary (accompanied by testimonials from the Captain), 30 March 1844, Governor [record group] (G) 1/11, NA.

73 Rogers to Saltonstall, 25 June 1842, US Despatches; Mugford to Rogers Bros., 23 August 1842, Governor [record group] (G) 1/11, NA.

74 Wasserman, pp.62-68.

75 Putnam, IV, p.47; Williams to Secretary of State, 3 January 1843 (arrival at Bay of Islands), 5 December 1842 (asks for a flag), US Despatches.

76 John Brown Williams, journal entry beginning December 1842, in Robert W. Kenny, ed., The New Zealand Journal 1842-1844 of John B. Williams of Salem, Massachusetts, Providence, RI, 1956, pp.31, 69.

77 Ibid, pp.66, 78.

78 Ibid, p.87.

79 Ibid, pp.75, 77, 81, 82.

80 Ibid, p.89; Ian Wards, Shadow of the Land: A Study of British Policy and Racial Conflict in New Zealand 1832-1852, Wellington, 1968, pp.97, 119; Jack Lee, I Have Named It the Bay of Islands, Auckland, 1996, pp.245, 250, 261, 271.

81 Williams to Secretary, (health affidavit), 9 February 1844, US Despatches; Williams to Secretary (recommendation about Fiji), 6 July 1844, US Despatches.

82 Hackler, pp.180-81; Wasserman, p.61; Williams to Secretary, 12 February 1844, US Despatches; Kenny, Williams Journal, Introduction.

83 Mayhew to Millet, 21 February 1844, US Despatches.

84 Mayhew to Secretary, 1 April 1844, US Despatches; Smith to Secretary, 15 May 1844, US Despatches; Ramsden, pp.281-2.

85 E.H. Norton, log, Elizabeth, Capt. Isaac Hedges, 6 May-5 June 1844, PMB 780, PEM.

86 Ramsden, pp.282-3, quotes from Edward Meurant's journal (9 June 1844), describing Busby's departure. All his goods were seized, but the bank was finally forced to return $£ 200$.

87 Police Magistrate to Smith, 24 January 1845, US Despatches.

88 Smith to Magistrate, 25 January 1845, US Despatches;

89 Magistrate to Smith, 25 January 1845, US Despatches.

90 Hackler, p.183. Smith was apprehended in the States, and repercussions reached as far as Downing Street: Grinnell (owner of ship American) to British Consul, 24 November 1845, US Despatches.

91 British Consul to Aberdeen, 24 February 1846, US Despatches; Gladstone to Governor Grey, 26 March 1846, US Despatches.

92 Polack to US Secretary of State, 23 June 1846, US Despatches.

93 New Zealander (NZ), 7 June 1845.

94 Thompson to Colonial Secretary, 7 June 1845, Internal Affairs (IA) 1/43, NA.

95 Colonial Secretary to Marine Surveyor, 7 June 1845, Internal Affairs (IA) 1/43, NA.

96 Williams to Secretary (about meeting up with ship I Don't Know in Port Nicholson), (undated), US Despatches. Williams had managed to get 67 captains and shipowners to 


\section{Journal of New Zealand Studies}

sign an affidavit asking for a consulate in Fiji, which undoubtedly helped his case with the State Department, 22 July 1844, US Despatches.

97 NZ, 13 September 1845; Williams to Secretary of State (protest about piracy of Falco), 22 September 1845, US Despatches; Salem Gazette (SG), 3 March 1846 (Falco a wreck).

98 Putnam, IV, pp.142-6 (Capt. Moseley's detailed report).

99 Williams to Secretary, 8 July 1845, US Despatches.

100 Stephen to Lord Stanley enclosing despatch from Gov. Grey of S. Australia, 4 November 1845, Governor [record group] (G) 1/15, NA; Lord Stanley to Grey, 2 Dec.1845, Governor [record group] (G) 1/15, NA.

101 Hackler, pp.183-4; US consular return 9 September 1845-1 January1846, with note about cargo of $R$. Pulsford, US Despatches; Polack to Secretary Buchanan with account of events, 23 June 1846, US Despatches; Williams to Secretary (about accusations of inciting rebellion), 14 July 1846, US Despatches.

102 Despatch, 22 October 1845, US Despatches.

103 Grey to Gladstone, 19 June 1846, Governor [record group] (G) 30/10, NA; Aberdeen's response, 18 November 1845, Governor [record group] (G) 1/15, NA.

104 State Department to Williams, 17 June 1846, US Despatches (opened by Polack, who forwarded it to Williams with a stiff covering letter).

105 Williams to Secretary, 14 July 1846, US Despatches.

106 Polack to Secretary, 30 November 1846, US Despatches.

107 Colonial Secretary to consulate, 16 September 1846, US Despatches; Polack to Colonial Secretary (letter copied to US Secretary of State), 9 November 1846, US Despatches.

108 Williams to Secretary, 1 January 1844 (deserters), US Despatches.

109 Capt. Nathaniel Hamlin, Nile, protest, 16 January 1847, US Despatches.

110 Capt. William Potter, Flora, protest, 28 January 1847, US Despatches.

111 Williams to Secretary (about appointing Fitzgerald), 18 April 1848, US Despatches.

112 Hackler, pp.186-9; Ramsden, p.289, states that this consul was James Busby's eldest son, J.D. Busby, but the bold, clear signature 'James Busby' on the US Despatches, which is identical to the signature on the earlier British Depatches, proves it was James himself. Busby's oldest child, John Dow Busby, born 26 June 1834, was just fourteen at the time. A son James had been born in 1838 but had died in 1840 .

113 Busby to Secretary, 31 January 1851, US Despatches; Busby to Secretary, 24 February, US Despatches; Busby to Secretary, 7 April 1851, US Despatches; Wasserman, pp.81-82.

114 H.M. Customs, affidavit about Waetford's 'appointment', 24 February 1851, US Despatches; Busby to Secretary, 12 March 1852, 14 April 1852, US Despatches.

115 Waetford to Secretary, 17 March 1853, US Despatches; Wasserman, p.125.

116 Williams died 19 June 1860 and is buried at Levuka. Kenny, Williams Journal, Introduction. James Busby remained in office until 2 January 1858, when Consul George P. West (of N. Carolina) arrived. Busby took over again in May 1859, after West dropped dead at his desk and did not finally retire until July 1860, when Consul George H. Leavenworth (of Vermont) arrived. 